\title{
Peningkatan kadar capsaicin tanaman Capsicum annuum cv. Lado pada kondisi kekeringan menggunakan kitosan
}

\author{
The increase of capsaicin level on Capsicum annuum cv. Lado under drought condition using chitosan

\begin{abstract}
Muhammad Abdul AZIZ1 ${ }^{1 *}$, Sri WAHYUNI ${ }^{1)}$, Fenny Martha DWIVANNY2)3) \& Rizkita Rachmi
\end{abstract} \\ ESYANTI $^{2)}$ \\ 1) Pusat Penelitian Bioteknologi dan Bioindustri Indonesia, Jl. Taman Kencana No. 1 Bogor, Indonesia 16128 \\ 2) Sekolah Ilmu dan Teknologi Hayati, Institut Teknologi Bandung, Jl. Ganeca 10, Bandung, Jawa Barat, Indonesia \\ 3) Pusat Penelitian Nanosains and Nanoteknologi, Institut Teknologi Bandung, Jawa Barat, Indonesia
}

Diterima tgl 16 Mar 2021 / disetujui tgl 19 Okt 2021

\begin{abstract}
Red chili pepper (Capsicum annuum) belongs to the vegetable with high economic value. However, drought stress decreases its survival, so that efforts to increase tolerance are needed. Chitosan is popular as a plant defense elicitor toward pathogen infection by inducing secondary metabolite synthesis of phenol group compounds such as capsaicin. This study aimed to determine the effect of $1 \mathrm{mg} \mathrm{mL}^{-1}$ of chitosan on the capsaicin level increment and expression level of the PAL1 gene of red chili cv. Lado under drought conditions. At the onset of the generative phase, plants were subjected to treatments including chitosan (Chi), Chitosan-drought (Chi-D), drought (D) and control (C). Observations were carried out by measuring the PAL1 gene expression level, PAL enzyme activity and capsaicin level. The results showed that $1 \mathrm{mg} \mathrm{mL}^{-1}$ chitosan application under drought conditions decreased PALl gene expression recorded at 0.61 and PAL enzyme activity at 0.94-fold compared to the control. Otherwise, the capsaicin level increased 2.46-fold compared to the control. Therefore, applying $1 \mathrm{mg}$ $m L-1$ chitosan on red chili plants under drought conditions was supposed to increase resistance towards pathogenic infections.
\end{abstract}

[Keywords: red chili pepper, PALl gene expression, secondary metabolite]

\footnotetext{
Abstrak

Cabai merah (Capsicum annuum) merupakan jenis sayuran yang memiliki nilai ekonomi tinggi. Saat kekeringan, kemampuan bertahan hidup tanaman tersebut sering kali menurun, sehingga diperlukan upaya untuk meningkatkan ketahanannya. Kitosan dikenal sebagai elisitor ketahanan tanaman terhadap infeksi patogen melalui induksi sintesis metabolit sekunder senyawa golongan fenol seperti capsaicin. Penelitian ini bertujuan untuk mengetahui pengaruh aplikasi kitosan $1 \mathrm{mg} \mathrm{mL} \mathrm{m}^{-1}$ terhadap

peningkatan kadar capsaicin dan ekspresi gen PAL1 tanaman cabai merah cv. Lado pada kondisi kekeringan. Serial perlakuan terdiri dari kitosan (Chi), kombinasi kitosan dan kekeringan (Chi-D), kekeringan (D) dan kontrol (C) yang diaplikasikan saat tanaman memasuki fase generatif. Parameter yang diamati meliputi analisis ekspresi gen PAL1, aktivitas enzim PAL dan kadar capsaicin. Hasil penelitian menunjukkan bahwa aplikasi kitosan 1 $\mathrm{mg} \mathrm{mL} \mathrm{mL}^{-1}$ saat kekeringan menurunkan level ekspresi gen PAL1 0,61 kali dan aktivitas enzim PAL 0,94 kali dibanding kontrol. Sebaliknya, kadar capsaicin meningkat 2,46 kali dibandingkan kontrol, sehingga aplikasi kitosan $1 \mathrm{mg} \mathrm{mL}^{-1}$ saat kekeringan diduga dapat meningkatkan ketahanan tanaman tersebut terhadap infeksi patogen.

[Kata Kunci: cabai merah, ekspresi gen PAL1, metabolit sekunder]

\section{Pendahuluan}

Cabai merah (C. annuum) merupakan tanaman yang tersebar luas dan sangat digemari hampir di seluruh dunia (Khan et al., 2014). Hal ini disebabkan oleh kandungan nutrisi seperti protein, lemak, vitamin, serat serta capsaicin yang menimbulkan sensasi pedas dan bermanfaat bagi kesehatan (Arora et al., 2011). Produksi cabai merah di Indonesia cenderung fluktuatif dan sering tidak dapat memenuhi kebutuhan pasar, sehingga berdampak pada kenaikan harga yang signifikan (KEMENTAN, 2016). Selain infeksi patogen, kekeringan juga merupakan salah satu faktor utama penyebab penurunan produktivitas yang signifikan pada komoditas ini. Oleh sebab itu, diperlukan solusi strategis untuk mengantisipasi berbagai stres lingkungan yang dialami tanaman. Pichyangkura \& Chadchawan (2015) dan Malerba \& Cerena (2016) menyatakan bahwa pemanfaatan material ramah lingkungan seperti kitosan untuk meningkatkan pertumbuhan sekaligus ketahanan tanaman menjadi terobosan yang menjanjikan untuk diaplikasikan di bidang pertanian. 
Kitosan merupakan senyawa alami turunan dari kitin, polisakarida yang terdapat pada eksoskeleton kelompok crustaceae seperti udang, lobster, kepiting, dan juga dinding sel jamur maupun selongsong pupa black soldier fly (BSF) (Mondal et al., 2012; Pichyangkura \& Chadchawan, 2015; Wahyuni et al., 2020). Kitosan dan derivatnya bersifat tidak beracun dan mudah terdegradasi oleh mikroba tanah, sehingga bersifat ramah lingkungan. Senyawa ini juga memiliki bioaktivitas antifungi, sehingga berfungsi sebagai biofungisida (Dzung et al., 2011) yang aplikasinya dapat dilakukan dengan cara penyemprotan pada daun (foliar spray) serta penyalutan (coating) pada buah-buahan, sayuran, dan biji. Kitosan banyak dikembangkan potensinya sebagai biostimulan yang dapat meningkatkan pertumbuhan sekaligus produktivitas (Dzung et al., 2011; Mukta el al., 2017 \& Mondal et al., 2012) dan ketahanan tanaman terhadap cekaman biotik maupun abiotik (Malerba \& Cerena, 2016; Wahyuni et al., 2019 \& Aziz et al., 2020a). Namun demikian, aktivitas kitosan yang diaplikasikan pada tanaman ketika tercekam belum banyak dipelajari.

Cekaman kekeringan merupakan salah satu stres lingkungan yang paling banyak terjadi khususnya di negara-negara tropis dan menjadi salah satu ancaman serius di bidang pertanian. Selama kekeringan, reactive oxygen species (ROS) seperti superoksida radikal, hidrogen peroksida, dan hidroksil peroksida diproduksi dalam jumlah berlebih sebagai signal terjadinya cekaman. Senyawa-senyawa tersebut bersifat toksik, sehingga tanaman akan merespons dengan memproduksi enzim-enzim antioksidan seperti katalase, peroksidase, dan polifenol oksidase untuk mendegradasinya (Khan et al., 2014). Tingginya ROS berkaitan dengan sintesis abcsisic acid (ABA) yang memediasi penutupan stomata, sehingga berakibat pada pertumbuhan maupun produktivitas yang terhambat (Iriti et al., 2009; \& Phimchan et al., 2012). Sung et al. (2005) menyatakan bahwa kekeringan pada tanaman cabai dapat menyebabkan bunga dan buah muda berguguran, sedangkan buah yang mampu bertahan memiliki plasenta yang tebal dengan kadar capsaicin lebih tinggi. Kadar capsaicin yang meningkat saat kekeringan diduga merupakan salah satu respons ketahanan tanaman terhadap infeksi patogen saat tercekam. Sementara itu, Khan et al. (2003) menambahkan bahwa salah satu mekanisme tanaman dalam meningkatkan ketahanan terhadap infeksi patogen adalah melalui regulasi metabolisme sekunder kelompok senyawa fenolik seperti capsaicin.

Capsaicin merupakan salah satu metabolit sekunder spesifik golongan fenol pada genus Capsicum yang disintesis melalui jalur phenylpropanoid dan fatty acid. Selain bertanggungjawab terhadap kepedasan dan ketahanan tanaman terhadap infeksi patogen, senyawa ini juga sangat potensial digunakan di bidang farmasi sebagai antiinflamasi, antioksidan, analgesik dan antikarsinogenik. Capsaicin dan dihydrocapsaicin merupakan komponen utama dari capsaicinoid yang disintesis dan terakumulasi di plasenta cabai (Gonzalez-zamora et al., 2013). Kadar capsaicin pada plasenta cabai merah defisit air mulai meningkat secara signifikan pada 10 hari setelah berbunga (HSB), kemudian mencapai titik maksimum pada 30 HSB yaitu sekitar 3,84 kali lebih tinggi dibanding kontrol (Sung et al., 2005). Khan et al. (2014) menyatakan bahwa peningkatan sintesis metabolit sekunder dapat meningkatkan toleransi stres abiotik. Selain itu, hasil penelitian sebelumnya juga mengungkapkan bahwa kadar capsaicin yang tinggi sejalan dengan peningkatan ketahanan tanaman terhadap infeksi Colletotrichum capsici (Kraikruan et al., 2008), Verticillium dahlia dan Phytopthora capsici (Veloso et al., 2013). Oleh sebab itu, akumulasi capsaicin dapat dijadikan sebagai salah satu parameter untuk mempelajari tingkat ketahanan tanaman cabai merah dalam merespons perubahan lingkungan.

$P A L$ merupakan family gene yang terdiri dari 4 anggota yaitu PAL1, PAL2, PAL3 dan PAL4. Gen PAL terekspresi hampir di semua organ tanaman cabai sebagai gen awal yang terekspresi pada jalur phenylpropanoid, pathway yang bertanggung jawab terhadap biosintesis metabolit sekunder golongan fenol seperti capsaicin. Masing-masing gen $P A L$ terekspresi secara kuat pada organ tertentu sebagai respons baik terhadap perkembangan tanaman maupun cekaman lingkungan (Kim \& Hwang, 2014). Gen PAL yang terekspresi kemudian ditranslasi menjadi protein aktif yaitu enzim phenylalanine ammonia lyase (PAL). PAL merupakan enzim yang berperan untuk mengkatalisis phenylalanine menjadi cinnamic acid. Kondisi stres kekeringan dapat memengaruhi aktivitas enzim PAL sebagai enzim pertama yang diaktifkan dalam biosintesis capsaicin (Sung et al., 2005). Penelitian ini bertujuan untuk mengetahui pengaruh aplikasi kitosan $1 \mathrm{mg} \mathrm{mL} \mathrm{mL}^{-1}$ terhadap peningkatan kadar capsaicin dan ekspresi gen PAL1 tanaman cabai merah ( $C$. annuum cv. Lado) pada kondisi kekeringan.

\section{Bahan dan Metode}

\section{Persiapan bahan dan perlakuan}

Studi pengaruh aplikasi kitosan dan kekeringan terhadap tanaman cabai merah (C. annuum) cv. Lado dilakukan di rumah kaca, ITB Bandung. Cabai merah cv. Lado merupakan komoditas komersil produksi PT. East West Seed Indonesia yang banyak dibudidayakan karena beberapa alasan seperti adaptif terhadap berbagai ketinggian lahan dan berpotensi menghasilkan 18-20 ton $\mathrm{Ha}^{-1}$ (PT. Ewindo, tidak dipublikasikan). Penelitian ini menggunakan rancangan acak kelompok (RAK) dengan 3 ulangan. Perlakuan terdiri dari kitosan 1 
mg $\mathrm{mL}^{-1}$ (Chi), kombinasi kitosan $1 \mathrm{mg} \mathrm{mL}^{-1}$ dan kekeringan (Chi-D), kekeringan (D) dan kontrol (C). Percobaan ini dilakukan selama \pm 112 hari dengan rata-rata fotoperiodisasi adalah 12 jam, kelembaban udara $78,96 \%$, intensitas cahaya 10.240 lux, dan suhu lingkungan $\pm 27,78^{\circ} \mathrm{C}$. Cabai merah ditanam dalam polybag berisi $3 \mathrm{~kg}$ media yang terdiri dari campuran tanah, sekam dan pupuk organik (4:3:2, v / v / v). Bibit cabai disiram sebanyak $\pm 200 \mathrm{~mL}$ air pada fase perkecambahan untuk menjaga kelembaban media, kemudian $1 \mathrm{~L}$ setiap 2 hari ketika sudah dipindahkan ke dalam polybag, yaitu selama 7 minggu atau sebelum memasuki fase generatif (Aziz et al., 2020b).

Ketika tanaman mulai memasuki fase pembungaan, ditandai oleh munculnya kuncup bunga, dilakukan perlakuan Chi, Chi-D, D dan C hingga 16 minggu setelah tanam (MST). Pada minggu ke 16 atau sekitar $55 \mathrm{HSB}$, dilakukan pengambilan sampel daun dan buah (Sung et al., 2005). Sekitar 55 HSB merupakan waktu panen untuk tanaman cabai merah cv. Lado (PT East West Seed Indonesia, tidak dipublikasikan), sehingga pada fase tersebut diduga kadar capsaicin berada di titik puncaknya. Sampel daun digunakan untuk ekstraksi RNA dan analisis aktivitas enzim PAL, sedangkan sampel buah digunakan untuk analisis kadar capsaicin.

Larutan kitosan $1 \mathrm{mg} \mathrm{mL} \mathrm{m}^{-1}$ yang disiapkan dengan mengacu pada Esyanti et al. (2019) dan Aziz et al. (2020a) disemprotkan satu minggu sekali dengan teknik foliar spray pada kelompok perlakuan Chi dan Chi-D. Perlakuan kekeringan dilakukan dengan memberikan penyiraman 50\% dari kebutuhan yaitu $500 \mathrm{~mL}$ air setiap 2 hari yang diberikan pada kelompok perlakuan D dan Chi-D
(Dorji et al., 2005). Penentuan kebutuhan air dilakukan dengan menghitung kapasitas lapang media yang digunakan (Aziz et al., 2020b).

Ekstraksi RNA, amplifikasi dan analisis qPCR gen PALI

RNA total diekstrak dari $50 \mathrm{mg}$ sampel daun cabai merah menggunakan kit ekstraksi RNA (mini PureLinkTM RNA, Invitrogen). Integritas RNA divalidasi dengan instrumen elektroforesis menggunakan gel agarosa $1,5 \% \quad(\mathrm{~b} / \mathrm{v})$ yang ditambah gelred. Konsentrasi dan kemurnian RNA yang diperoleh ditentukan menggunakan spektrofotometer nanodrop (Eppendorf, biospectrometer). Perlakuan DNAse dilakukan dengan menggunakan DNAseI (Thermo Scientific), sementara cDNA disintesis menggunakan iScript cDNA Synthesis Kit dari Bio-Rad. Setelah itu, kualitas cDNA divalidasi menggunakan gel agarosa $2 \%$ dengan CaUbi3 sebagai gen referensi dengan primer spesifik (Tabel 1). Kondisi PCR (thermal cycler) dilakukan sesuai protokol pada Tabel 2.

Amplifikasi PALl dilakukan menggunakan primer spesifik (Tabel 1). Setelah ukuran fragmen DNA hasil amplifikasi terkonfirmasi sesuai dengan primer yang didesain sebelumnya, dilakukan sekuensing melalui jasa Macrogen, Korea. PCR kuantitatif (qPCR) dilakukan menggunakan instrumen dari MyGo Pro dan pewarna dari Toyobo (Thunderbirds Sybr qPCR Mix QPS-201). Nilai melting temperature (TM) digunakan untuk mengetahui spesifisitas primer, sementara nilai siklus kuantifikasi $(\mathrm{Cq})$ digunakan untuk mengukur level ekspresi gen target.

Tabel 1. Primer untuk gen PAL1 and CaUbi3

Table 1. The PAL1 and CaUbi3 genes primers

\begin{tabular}{lllc}
\hline \multicolumn{1}{c}{$\begin{array}{c}\text { Primer } \\
\text { Primer }\end{array}$} & \multicolumn{1}{c}{$\begin{array}{c}\text { Nomor aksesi } \\
\text { Accession number }\end{array}$} & \multicolumn{1}{c}{$\begin{array}{c}\text { Nucleotida (5' to 3')0 } \\
\text { Nucleotides (5' to 3') }\end{array}$} & $\begin{array}{c}\text { Ukuran (bp) } \\
\text { Size (bp) }\end{array}$ \\
\hline $\begin{array}{l}\text { PAL1 } \\
\text { Forward }\end{array}$ & NM_001324603 & & 283 \\
$\begin{array}{l}\text { Reverse } \\
\text { CaUbi3 }\end{array}$ & AY486137.1 & TGGGCTTAATCTCATCAAGG & 201 \\
$\begin{array}{l}\text { Forward } \\
\text { Reverse }\end{array}$ & & TAGGTTGAGCTGCAGGTATC & \\
\hline
\end{tabular}

Tabel 2. Protokol amplifikasi gen $P A L 1$ dan CaUbi3

Table 2. The amplification of PAL1 and CaUbi3 genes protocol

\begin{tabular}{lccccc}
\hline \multicolumn{5}{c}{ Siklus PCR } \\
& $\begin{array}{c}\text { PCR Cycles } \\
\text { Denaturasi awal } \\
\text { Earlyaturation }\end{array}$ & $\begin{array}{c}\text { Denaturasi } \\
\text { Denaturation }\end{array}$ & $\begin{array}{c}\text { Penempelan } \\
\text { Annealing }\end{array}$ & $\begin{array}{c}\text { Elongasi } \\
\text { Elongation }\end{array}$ & $\begin{array}{c}\text { Elongasi akhir } \\
\text { Late elongation }\end{array}$ \\
\hline $\begin{array}{l}\text { Suhu } \\
\text { Temp. }\end{array}$ & $95^{\circ} \mathrm{C}$ & $95{ }^{\circ} \mathrm{C}$ & $58^{\circ} \mathrm{C}$ & $72^{\circ} \mathrm{C}$ & $72{ }^{\circ} \mathrm{C}$ \\
$\begin{array}{l}\text { Waktu } \\
\text { Time }\end{array}$ & 3, & $30^{\prime}$, & 30, & 1 & 5 \\
\hline $\begin{array}{l}\text { Siklus } \\
\text { Cylces }\end{array}$ & $1 \mathrm{x}$ & & $35 \mathrm{x}$ & & $1 \mathrm{x}$ \\
\hline
\end{tabular}


Kuantifikasi level ekspresi gen target dilakukan melalui metode relatif menggunakan persamaan 2 $\Delta \Delta \mathrm{Cq}$. Perhitungan dilakukan dengan melakukan normalisasi terhadap nilai $\mathrm{Cq}$ gen referensi dan kelompok kontrol terlebih dahulu dengan mengikuti persamaan berikut (Livak dan Schmittgen, 2001):

$$
\begin{aligned}
\Delta \Delta C q= & \left(C q_{\text {gen target }}-C q_{\text {gen ref }}\right) \text { sampel }-\left(C q_{\text {gen target }}\right. \\
& \left.-C q_{\text {gen ref. }}\right) \text { kalibrator } / \text { kontrol }
\end{aligned}
$$

\section{Analisis aktivitas enzim PAL}

Aktivitas enzim PAL dianalisis berdasarkan metode Sung et al. (2005), dengan beberapa modifikasi. Sebanyak 0,5 gr daun cabai dihaluskan menggunakan bantuan nitrogen cair, kemudian ditambahkan $3 \mathrm{~mL}$ buffer ekstraksi protein yang mengandung $50 \mathrm{mM}$ Tris- $\mathrm{HCl} \mathrm{pH} 8,1 \mathrm{mM}$ EDTA, $15 \mathrm{mM} \beta$-mercaptoethanol, dan $50 \mathrm{mM}$ asam askorbat. Sampel dihomogenkan dengan kecepatan tinggi selama 1 menit melalui bantuan vortex, kemudian disentrifus pada $7000 \mathrm{rpm}$ selama 40 menit. Supernatan disentrifus kembali pada 10.000 rpm selama 10 menit, kemudian dipindahkan ke tabung baru dan ditambahkan $5 \mathrm{~mL}$ buffer Tris- $\mathrm{HCl} 50 \mathrm{mM} \mathrm{pH} \mathrm{8.} \mathrm{Total} \mathrm{protein}$ diukur menggunakan metode Bradford (Bradford, 1976), yaitu dengan cara menambahkan $20 \mu \mathrm{L}$ ekstrak protein ke dalam $980 \mu \mathrm{L}$ reagen Bradford, kemudian diinkubasi pada suhu kamar selama 5 menit. Absorbansi diukur menggunakan spektrofotometer UV-VIS (AMTAST AMV11) pada $\lambda_{595} \mathrm{~nm}$. BSA (Bovine Serine Albumin) digunakan sebagai larutan standar pada konsentrasi $0 ; 1 ; 2,5 ; 5 ; 10$ dan 15 ppm.

Uji aktivitas enzim PAL dilakukan dengan mencampurkan $1 \mathrm{~mL}$ Tris- $\mathrm{HCl} 100 \mathrm{mM}, 0,5 \mathrm{~mL}$ L-fenilalanin $10 \mathrm{mM}, 0,4 \mathrm{~mL}$ air deion steril, dan 0,1 mL ekstrak protein. Campuran diinkubasi pada suhu kamar selama 1 jam. Reaksi dihentikan dengan menambahkan $0,5 \mathrm{~mL} \mathrm{HCl} 6 \mathrm{M}$. Sebanyak 7,5 mL dietil eter ditambahkan untuk mengikat senyawa polar. Campuran disimpan pada freezer $20^{\circ} \mathrm{C}$. Setelah 2 fase terbentuk, dietil eter dibuang. Fase beku dikeringkan menggunakan freeze dryer selama 24 jam, kemudian dilarutkan dengan $3 \mathrm{~mL}$ $\mathrm{NaOH} 50 \mathrm{mM}$. Absorbansi diukur pada $\lambda_{290} \mathrm{~nm}$. Kuantifikasi aktivitas enzim PAL dilakukan dengan cinnamic acid sebagai standar pada konsentrasi $0 ; 0,3125 ; 0,625 ; 1,25$ dan 2,5 ppm (Sung et al., 2005).

\section{Analisis kadar capsaicin plasenta cabai merah}

Capsaicin diekstrak dari plasenta cabai menggunakan metode maserasi (Goci et al., 2014). Kuantifikasi kadar capsaicin dilakukan dengan mengacu pada metode Sung et al. (2005) menggunakan high performance liquid chromatography (HPLC, C-R7A Plus Chromatopac, Shimadzu). Plasenta dipisahkan dari buah cabai kemudian dikeringkan pada suhu $60^{\circ} \mathrm{C}$ selama 30 jam. Sampel dihaluskan dan dimaserasi dalam $5 \mathrm{~mL}$ ethanol $96 \%$ selama 24 jam dengan bantuan shaker. Sampel yang telah dimaserasi selanjutnya disaring dalam gelas kimia $50 \mathrm{~mL}$, kemudian diinkubasi pada suhu ruang agar ethanol menguap. Filtrat kering dilarutkan menggunakan 1 $\mathrm{mL}$ methanol $100 \%$ kemudian disaring kembali dengan kapas bebas lemak untuk segera diuji atau disimpan pada suhu $4^{\circ} \mathrm{C}$.

Sebanyak 2,5 $\mu \mathrm{L}$ ekstrak diinjeksi ke dalam sistem HPLC. Campuran asetonitril dan aqua bides pada rasio $6: 4(\mathrm{v}: \mathrm{v})$ dengan laju aliran $0,7 \mathrm{~mL}$ per menit selama 12 menit per sampel digunakan sebagai fase gerak. Sebelum digunakan, aseonitril disaring menggunakan filter polytetraflouroethylene (PTFE), sementara aqua bides disaring menggunakan membran nitroselulosa. Konsentrasi capsaicin ditetapkan dengan mengukur absorbansi pada $\lambda_{280} \mathrm{~nm}$, dengan larutan standar capsaicin (SIGMA, Lot \#BCBJ2271V) pada konsentrasi 0; 125; 250; dan 500 ppm.

\section{Analisis statistik}

Perbedaan signifikansi antar perlakuan ditentukan dengan uji Tukey HSD $(p<0,05)$ menggunakan perangkat lunak $\mathrm{R}$ studio 3.5.2 (32/64 bit). Sementara pengaruh aplikasi kitosan, Kekeringan dan interaksi antar kedua perlakuan terhadap parameter level ekspresi gen PAL1, aktivitas enzim PAL dan kadar capsaicin dianalisis menggunakan Two-way ANOVA yang dilakukan menggunakan aplikasi IBM SPSS 22.

\section{Hasil dan Pembahasan}

Pengaruh pemberian kitosan pada kondisi kekeringan terhadap level ekspresi dan aktivitas $P A L$

Hasil pengujian menunjukkan terbentuknya 2 pita (Gambar 1A) dengan kemurnian RNA (rasio $\lambda_{260}$ dan $\lambda_{280}$ ) berkisar antara $2,12-2,14$, sementara konsentrasinya berkisar antara $353,1-410,9 \mu \mathrm{g}$ $\mathrm{mL}^{-1}$. Terbentuknya 2 pita dengan tingkat kemurnian tersebut menjadi syarat utama untuk memenuhi validitas pengujian, sementara konsentrasi RNA digunakan sebagai acuan dalam sintesis cDNA. Setelah total RNA diubah menjadi cDNA, selanjutnya dilakukan amplifikasi menggunakan primer spesifik gen target.

Berdasarkan hasil studi secara in silico, dengan menggunakan primer spesifik (Tabel 1) akan diperoleh pita produk dengan ukuran sekitar 201 untuk CaUbi3 dan 284 bp untuk PAL1. Pada penelitian ini, CaUbi3 berperan sebagai gen referensi yang digunakan untuk normalisasi level ekspresi gen target serta untuk memvalidasi hasil sintesis cDNA (Livak \& Schmittgen, 2001). cDNA yang berhasil disintesis terkonfirmasi dari satu pita yang terbentuk sesuai dengan ukuran yang didesain. Produk amplifikasi gen PAL1 dan CaUbi3 yang disertai dengan kontrol negatif (K-) divisualisasikan secara bersamaan (Gambar 1B). 
Setelah dilakukan analisis sekuensing menggunakan perangkat basic local alignment searching tool (BLAST), dihasilkan tingkat kesamaan (identity value) sebesar 97\% terhadap gen CaPAL1 (accession number: NM_001324603).

Nilai Tm (melting temperature) pada setiap sampel teramati pada satu nilai yang sama yaitu antara $85-90^{\circ} \mathrm{C}$ yang menandakan bahwa proses amplifikasi secara spesifik terjadi pada satu gen target (Gambar 2A). Sementara itu, Cq menunjukkan nilai siklus yang mana gen target pada sampel mengalami amplifikasi di fase eksponensial. Nilai $\mathrm{Cq}$ antara kelompok perlakuan dan non template control (NTC) dapat dijadikan sebagai acuan validitas reaksi pada proses qPCR. Nilai $\mathrm{Cq}$ pada kelompok NTC harus tidak terdeteksi atau terdeteksi dengan nilai lebih tinggi dibanding kelompok perlakuan (Gambar 2B). Nilai $\mathrm{Cq}$ ini digunakan untuk mengkuantifikasi level ekspresi baik secara relatif maupun mutlak (Livak \& Schmittgen, 2001).

Berdasarkan hasil kuantifikasi level ekspresi gen PAL1, dapat diketahui bahwa terjadi perbedaan level ekspresi yang signifikan pada setiap perlakuan. Namun demikian, jika dibandingkan dengan kontrol, terjadi penurunan level ekspresi pada setiap kelompok perlakuan. Level ekspresi yang teramati pada kelompok perlakuan kitosan saat kekeringan (Chi-D) adalah
0,61 kali dibandingkan kontrol, kemudian disusul kelompok kitosan (Chi) dan kekeringan (D) secara berturut-turut yaitu 0,22 dan 0,10 kali dibandingkan kontrol (Gambar 3A). Hal tersebut tidak sejalan dengan hasil penelitian sebelumnya pada kultivar yang lain. Telah dilaporkan bahwa level ekspresi gen $P A L$ meningkat 12 kali oleh aplikasi kitosan $1 \mathrm{mg} \mathrm{mL}^{-1}$ (Mejia-teniente et al., 2013) dan 3,61 kali karena cekaman kekeringan (Khan et al., 2014) pada tanaman cabai.

Perubahan level ekspresi gen $P A L$ merupakan salah satu respons ketahanan tanaman saat tercekam. Perbedaan respons ketahanan yang teramati berdasarkan hasil analisis level ekspresi PAL1 pada tanaman cabai merah cv. Lado diduga terjadi karena pengaruh tingkat ketahanan dan perbedaan umur fisiologis antar kultivar tanaman. C. annuиm cv. Lado diketahui memiliki ketahanan yang rendah terhadap penyakit baik yang disebabkan oleh bakteri maupun jamur patogen dengan masa panen yang relatif panjang yaitu sekitar 100 - 120 hari setelah tanam (PT. East West Seed Indonesia, tidak dipublikasikan). Umur fisiologis tanaman cabai berkaitan dengan ketahanan terhadap infeksi patogen, karena biosintesis capsaicin sebagai salah satu regulator ketahanan berfluktuasi seiring dengan tingkat kematangan buah dan cekaman lingkungan (Sung et al., 2005). C. annum cv. Laba diketahui memiliki ketahanan terhadap penyakit yang lebih

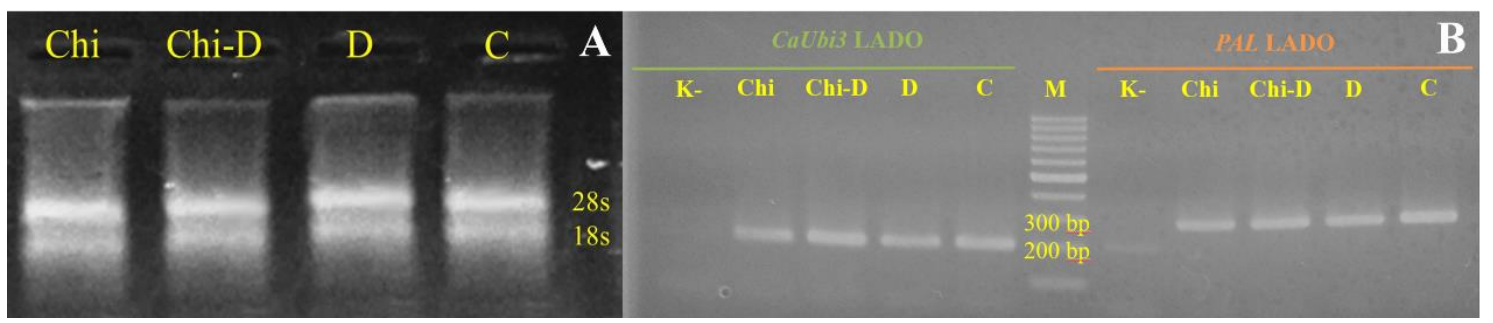

Gambar 1. Elektroforegram RNA total (A) dan hasil PCR gen referensi (CaUbi3) serta gen target (PAL1) tanaman cabai merah (C. annuum cv. Lado) (B). Chi = kitosan; Chi-D = kombinasi kitosan dan kekeringan; $\mathrm{D}=$ kekeringan; dan $\mathrm{C}=$ kontrol; $\mathrm{K}-=$ kontrol negatif dan $\mathrm{M}=$ marker

Figure 1. The electroforegram of the total RNA (A) and PCR product of CaUbi3 housekeeping gene and also PAL1 gene of red chili pepper (C. annuum $c v$. Lado) (B). Chi = chitosan; Chi-D = chitosan and drought; $D=$ drought; $C=$ control $; K-=$ negative control; and $M=$ marker

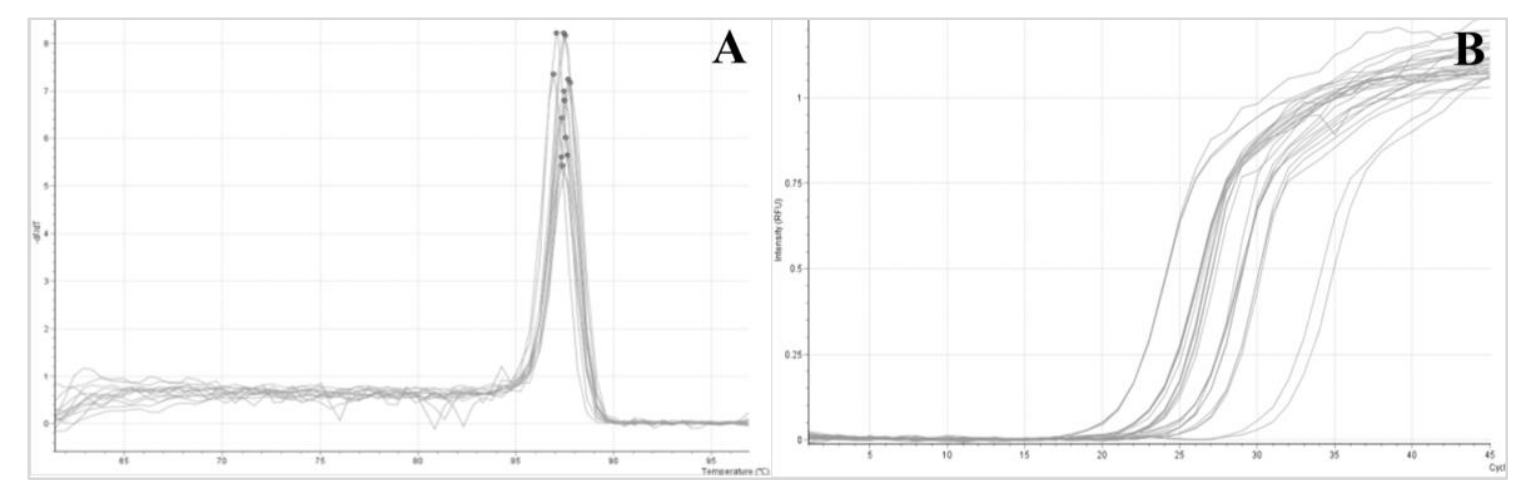

Gambar 2. Nilai $\mathrm{Tm}(\mathrm{A})$ dan $\mathrm{Cq}(\mathrm{B})$ pada proses amplifikasi gen target menggunakan sistem qPCR

Figure 2. $T m(A)$ and $C q(B)$ values on the amplification of the target gene using qPCR system 

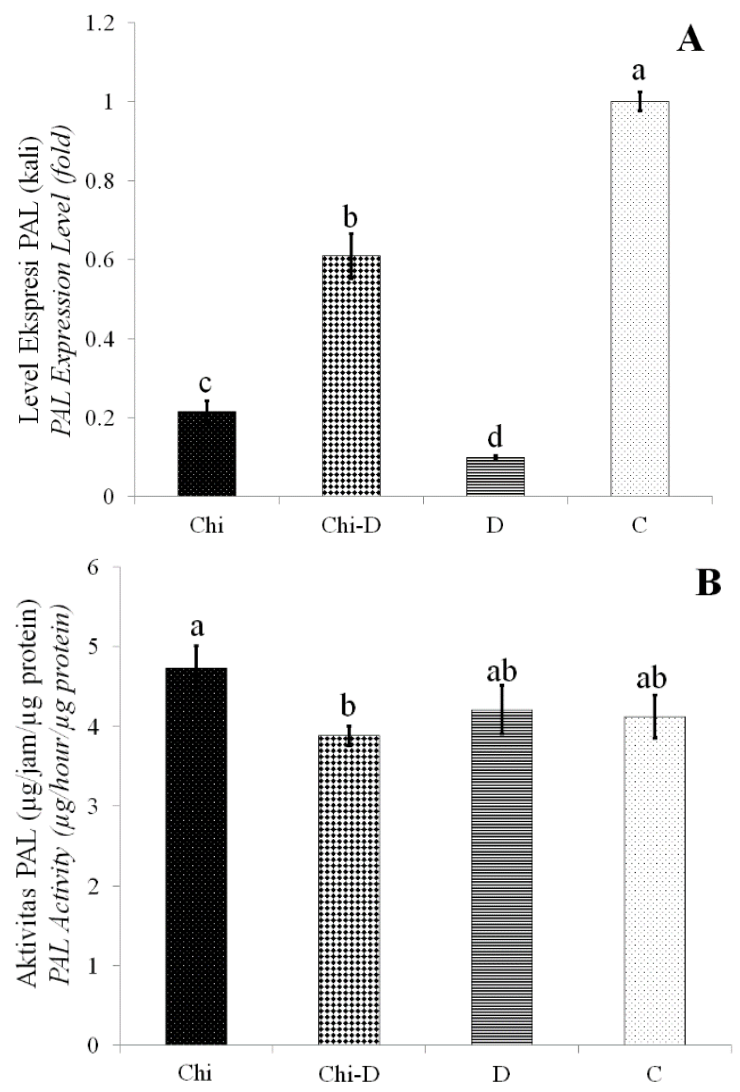

Gambar 3. Pengaruh kitosan saat kekeringan terhadap level ekspresi $P A L 1$ (A) dan aktivitas enzim PAL tanaman cabai merah (B). Bar pada setiap kelompok perlakuan menunjukkan nilai standar eror dari nilai rata-rata $(\mathrm{n}=3)$. Nilai signifikansi ditentukan oleh perbedaan huruf pada setiap bar pada taraf $p<0,05$. Chi $=$ kitosan; Chi-D = kombinasi kitosan dan kekeringan; $\mathrm{D}=$ kekeringan; dan $\mathrm{C}=$ kontrol

Figure 3. The effect of chitosan under drought condition to PAL1 expression level (A) and $P A L$ activity on red chili plant $(B)$. The bars indicate the mean of each growth parameters with corresponding standard error $(n=3)$. Significance value is indicated by the difference letter on top of each bar, $p<0.05$. Chi = chitosan; Chi-D = chitosan and drought; $D=$ drought; $C=$ control

tinggi dibandingkan $C$. апnиит $\mathrm{cv}$. Lado dengan masa panen yang lebih singkat yaitu sekitar 90-100 hari setelah tanam. Aziz et al. (2020a) menyatakan bahwa cabai merah cv. Laba teramati sangat responsif terhadap perlakuan kitosan, kekeringan, maupun kombinasinya yang ditunjukkan oleh perubahan level ekspresi gen-gen ketahanan seperti WRKY17 dan WRKY53. Oleh sebab itu, diduga terdapat perbedaan fluktuasi level ekspresi gen $P A L 1$ selama fase pematangan buah setelah perlakuan kitosan, kekeringan, maupun kombinasinya pada kultivar Lado. Di samping itu, pada penelitian ini level ekspresi gen PALl hanya diamati pada organ daun. Dengan demikian, diduga PAL1 dari organ daun tidak responsif terhadap perlakuan kitosan maupun kekeringan pada fase pematangan buah. Selain ditentukan oleh ekspresi gen $P A L 1$, aktivitas enzim PAL dan kadar metabolit sekunder capsaicin juga ditentukan oleh level ekspresi gen $P A L$ yang lain.

Hasil penelitian menunjukkan bahwa aktivitas enzim PAL tertinggi terjadi pada kelompok perlakuan kitosan (Chi) yaitu sebesar $4,73 \mu \mathrm{g} /$ $\mathrm{jam} / \mu \mathrm{g}$ protein, yang berbeda signifikan terhadap kelompok kombinasi kitosan dan kekeringan (ChiD) yaitu $3,88 \mu \mathrm{g} / \mathrm{jam} / \mu \mathrm{g}$ protein. Sementara itu, pada perlakuan kekeringan (D) dan kontrol (C) teramati sebesar 4,21 dan $4,14 \mu \mathrm{g} / \mathrm{jam} / \mu \mathrm{g}$ protein secara berturut-turut (Gambar 3B). Berdasarkan hasil tersebut dapat diketahui bahwa aplikasi kitosan $1 \mathrm{mg} \mathrm{mL}^{-1}$ secara tunggal berpotensi untuk meningkatkan aktivitas enzim PAL. Hal ini didukung oleh Khan et al. (2003) yang menyatakan bahwa aplikasi kitosan oligomer dapat meningkatkan aktivitas PAL pada daun tanaman kedelai yang diperkirakan berperan sebagai gejala awal terhadap stres, baik berupa elisitasi ataupun infeksi patogen. Aktivitas PAL pada kelompok Chi-D menunjukkan nilai terendah dan juga berbeda signifikan terhadap kelompok kitosan. Hal ini menandakan bahwa kombinasi aplikasi tersebut diduga dapat menurunkan aktivitas PAL. Fenomena ini diperkirakan terjadi karena stres berlebih yang dialami tanaman seiring kombinasi perlakuan yang diberikan. Stres yang terjadi pada tanaman dapat memicu peningkatan level reactive oxygen species (ROS) yang berlebih, sehingga dapat menyebabkan kerusakan oksidatif pada protein, DNA, maupun lipid (Anjum et al., 2011). Tinggi rendahnya aktivitas PAL akan berpengaruh terhadap jalur biosintesis metabolit sekunder golongan fenol yang melibatkan phenylalanine sebagai prekursor utamanya. Khan et al. (2014) menyampaikan bahwa PAL dan capsaicin synthetase (CS) merupakan 2 enzim kunci yang berperan dalam biosintesis capsaicin.

Pengaruh pemberian kitosan saat kekeringan terhadap kadar capsaicin

Hasil penelitian menunjukkan bahwa aplikasi kitosan pada kondisi kekeringan (Chi-D) dapat meningkatkan kadar capsaicin secara signifikan, yaitu sebesar 2,46 kali dibanding kontrol. Jika dibandingkan dengan perlakuan kitosan (Chi) dan kekeringan (D), secara berturut-turut teramati peningkatan yang signifikan sebesar 1,39 hingga 1,62 kali lebih tinggi (Gambar 4). Hasil tersebut didukung oleh Sung et al. (2005) yang menyatakan bahwa kekeringan 50\% dapat meningkatkan kadar capsaicin di plasenta cabai merah sebesar 2,56 kali lebih tinggi dibanding kontrol. Selain itu, Khan et al. (2003) menambahkan bahwa aplikasi kitosan oligomer dapat meningkatkan kadar total fenol tanaman kedelai yang diperkirakan sejalan dengan peningkatan aktivitas enzim PAL. Dengan demikian dapat diketahui bahwa baik aplikasi kitosan (Chi) maupun kekeringan (D) berpotensi 


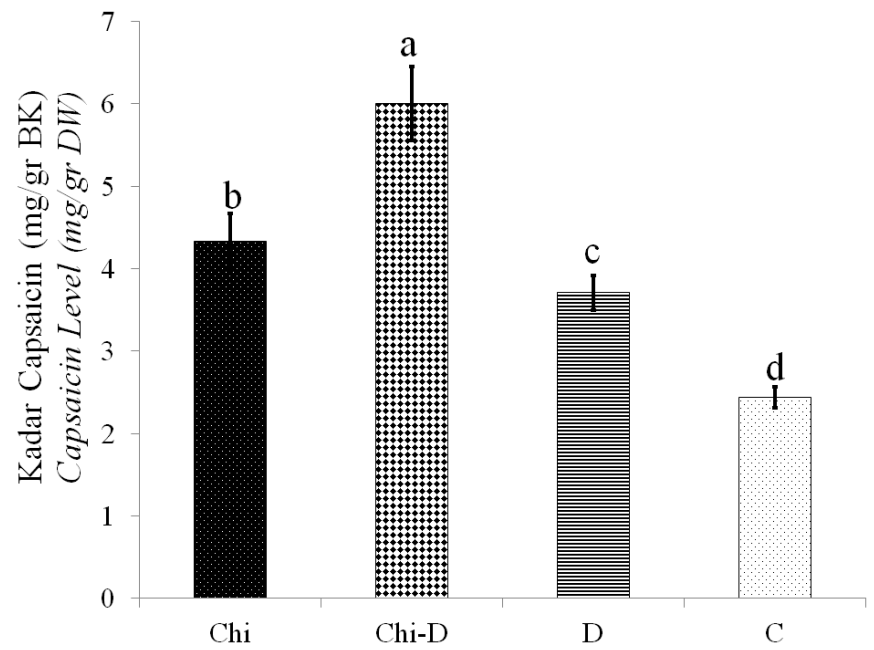

Gambar 4. Pengaruh perlakuan kombinasi kitosan dan kekeringan terhadap kadar capsaicin cabai merah. Bar pada setiap kelompok perlakuan menunjukkan nilai standar eror dari nilai rata-rata $(\mathrm{n}=3)$. Nilai signifikansi ditentukan oleh perbedaan huruf pada setiap bar pada taraf $p<0,05 . \mathrm{BK}=$ berat kering; $\mathrm{Chi}=$ kitosan; $\mathrm{Chi}-\mathrm{D}=$ kombinasi kitosan dan kekeringan; $\mathrm{D}=$ kekeringan; dan $\mathrm{C}=$ kontrol

Figure 4. The effect of kitosan and drought treatment combination to capsaicin level on red chili plant. The bars indicate the mean of each growth parameters with corresponding standard error $(n=3)$. Significance value is indicated by the difference letter on top of each bar, $p<0.05 . D W=$ Dry weight; Chi = chitosan; Chi-D = chitosan and drought; $D=$ drought C = control

menyebabkan peningkatan kadar metabolit sekunder golongan fenol seperti capsaicin, kemudian kombinasi keduanya berpotensi menyebabkan peningkatan yang lebih tinggi.

Biosintesis capsaicin terjadi di dalam sel-sel epidermis plasenta yang diakumulasikan dalam bentuk blister, kemudian disekresikan menuju lapisan sel terluar pericarp buah cabai. Senyawa ini disintesis melalui kondensasi vanillylamine yang diperoleh dari jalur sintesis phenylpropanoid dan fatty acid. Jalur sintesis phenylpropanoid menentukan struktur fenol, sementara jalur fatty acid menentukan gugus lemak (Gonzalez-zamora et al., 2013). Tahap awal dari jalur phenylpropanoid adalah sintesis cinnamic acid dari prekursor phenylalanine dengan menggunakan katalis phenylalanine ammonia lyase (PAL) yang terjadi baik pada batang maupun daun. Sementara untuk jalur asam lemak menggunakan asam amino valine sebagai prekursornya. Gen $P A L$ bertanggungjawab sebagai gen awal dalam produksi metaboit sekunder melalui jalur phenylpropanoid, sedangkan gen $C S$ merupakan gen yang terekspresi di plasenta buah cabai dan berperan terhadap pembentukan capsaicin (Arora et al., 2011; Kim \& Hwang, 2014).

Berdasarkan hasil yang diperoleh, peningkatan kadar capsaicin yang signifikan pada perlakuan Chi-D diperkirakan karena respons sinergis oleh tanaman terhadap kombinasi perlakuan kitosan dan kekeringan (Iriti et al., 2009), sehingga dapat menstimulasi respons ketahanan yang lebih tinggi dengan mensintesis metabolit sekunder capsaicin dalam jumlah berlebih. Hal ini sejalan dengan Khan et al. (2014) bahwa aplikasi jamur endofit $P$. resedanum LK6 saat kekeringan secara signifikan dapat meningkatkan kadar capsaicin cabai merah yang diikuti dengan peningkatan ekspresi gen $P A L$ dan $C S$. Kekeringan dan aplikasi kitosan pada umumnya dapat menginduksi jalur signalling yang sama yaitu melalui produksi abscisic acid (ABA) dan jasmonic acid (JA) (Golldack et al., 2014; Pichayangkura \& Chadchawan, 2015). Adanya JA dapat menginduksi aktifnya gen $P A L$, sementara tingginya ABA sejalan dengan peningkatan aktivitas enzim PAL (Wasternack, 2013; Ibrahim \& Jaafar, 2013), sehingga diduga kadar capsaicin yang paling tinggi oleh aplikasi kitosan saat kekeringan berkaitan dengan jalur signalling tersebut.

Pada penelitian ini, rendahnya level ekspresi gen $P A L 1$ dan aktivitas enzim PAL tidak sejalan dengan peningkatan kadar capsaicin yang signifikan lebih tinggi pada kelompok perlakuan Chi-D. Fenomena ini dapat terjadi karena beberapa faktor seperti pengaruh waktu aplikasi, intensitas aplikasi dan konsentrasi kitosan (Mejia-teniente et al., 2013) terhadap fluktuasi ekspresi gen-gen terkait ketahanan seperti $P A L$. Selain itu, diduga umur fisiologis tanaman juga berpengaruh terhadap fluktuasi ekspresi gen-gen ketahanan saat fase pematangan buah. Dengan demikian, pengambilan sampel daun yang dilakukan pada 55 hari setelah berbunga kemungkinan bukan saat dimana ekspresi gen PAL1 berada pada titik kulminasinya. Selain itu, ekspresi gen $P A L$ dan aktivitas enzim PAL dari organ lain baik akar maupun batang diperkirakan berkontribusi dalam menyumbang prekursor cinnamic acid yang merupakan produk dari aktivitas enzim PAL. Gonzalez-zamora et al. (2013) menyatakan bahwa 
capsaicin terbentuk melalui jalur phenylpropanoid dan fatty acid yang melibatkan asam amino phenylalanine dan valine sebagai prekursor utama. Produk akhir dari 2 jalur biosintesis tersebut bertanggungjawab terhadap akumulasi capsaicin. Selain itu, Kim \& Hwang (2014) menyatakan bahwa gen PAL1, PAL2, dan PAL4 terekspresi kuat pada sel-sel yang mengalami lignifikasi, sementara ekspresi gen PAL3 rendah.

Pemanfaatan potensi kitosan di bidang pertanian sebagai biostimulan pertumbuhan dan elisitor ketahanan tanaman terhadap infeksi patogen menjadi terobosan yang menjanjikan (Pichyangkura \& Chadchawan, 2015; Malerba \& Cerena, 2016). Aplikasi kitosan terhadap cabai merah sebagai salah satu komoditas penting di Indonesia saat tercekam kekeringan memperkaya wawasan bagi ilmuan maupun petani dalam mengeksplorasi potensi kitosan lebih dalam. Berdasarkan hasil studi, telah diungkapkan pengaruh kitosan dalam meningkatkan kadar capsaicin baik pada kondisi normal maupun kekeringan. Oleh sebab itu, hasil studi ini dapat menjadi rekomendasi bagi petani dalam memanfaatkan kitosan untuk meningkatkan ketahanan tanaman terhadap infeksi patogen. Namun demikian, studi lebih lanjut dapat dilakukan untuk mempelajari aplikasi beberapa dosis kitosan pada kondisi cekaman yang berbeda, kemudian pengamatan terhadap karakter ketahanan tanaman dilakukan secara komprehensif pada beberapa umur fisiologis yang berbeda.

\section{Kesimpulan}

Perlakuan aplikasi kitosan $1 \mathrm{mg} \mathrm{mL} \mathrm{mL}^{-1}$ saat kekeringan dapat meningkatkan kadar capsaicin 2,46 kali dibanding kontrol, sehingga aplikasi kitosan diduga dapat meningkatkan ketahanan tanaman terhadap infeksi patogen saat kekeringan. Sementara itu, level ekspresi gen PALl dan aktivitas enzim PAL pada organ daun tanaman cabai merah cv. Lado sedikit menurun. Penelitian lebih lanjut perlu dilakukan untuk mempelajari level ekspresi anggota family gene $P A L$ lainnya (PAL2, PAL3 dan PAL4) secara komprehensif dengan perlakuan kekeringan dan kitosan selama fase pematangan buah.

\section{Ucapan Terimakasih}

Penelitian ini didanai oleh Lembaga Pengelola Dana Pendidikan (LPDP) tahun 2018, Kementeruian Keuangan Republik Indonesia. Benih cabai merah kultivar Lado diperoleh dari PT East West Seed Indonesia (PT. Ewindo).

\section{Daftar Pustaka}

Anjum SA, X Xie, L Wang, MF Saleem, C Man \& W Lei (2011). Morphological, physiological, and biochemical responses of plants to drought stress. African Journal of Agricultural Research 6(9), 2016-2032.

Arora RS, NG Gill, C Chauhan \& A Rana (2011). An overview about versatile molecule capsaicin. International Journal of Pharmaceutical Sciences and Drug Research 3, 280-286.

Aziz MA, RE Esyanti \& FM Dwivanny (2020a). Pengaruh kitosan terhadap peningkatan level ekspresi WRKY17 dan WRKY53 tanaman Capsicum annuum cv. Laba pada kondisi kekeringan. Menara Perkebunan 88(2), 120129.

Aziz MA, RE Esyanti, K Meitha, FM Dwivany \& $\mathrm{HH}$ Chotimah (2020b). Chitosan suppresses the expression level of WRKY17 on red chili (Capsicum annuum) plant under drought stress. Indonesian Journal of Biotechnology, 25(1), 52-60.

Bradford MM (1976). A rapid and sensitive method for the quantitation of microgram quantities of protein utilizing the principle of protein-dye binding. Anal. Biochem, 72: 248254.

Dorji K, MH Behboudian \& JA Zegda-dominguez (2005). Water relations, growth, yield, and fruit quality of hot pepper under deficit irrigation and partial rootzone drying. Scientia Horticulturae 104, 137-149.

Dzung NA, VTP Khanh \& TT Dzung (2011). Research on impact of chitosan oligomers on biophysical characteristic, growth, development, and drought resistance of coffee. Carbohydrate Polymers 84, 751-755.

Esyanti RR, FM Dwivany, S Mahani, H Nugrahapraja \& K Meitha (2019). Foliar application of chitosan enhances growth and modulates expression of defense genes in chili pepper (Capsicum annuum L.). Aust J Crop Sci 13(1), 55-60.

Goci E, E Haloci, K Vide \& L Malaj (2013). Application and comparison of three different extraction methods of capsaicin from capsicum fruits. Albanian Journal of Pharmaceutical Sciences 1(1), 16-19.

Golldack D, C Li, H Mohan \& N Probst (2014). Tolerance to drought and salt stress in plants: unrevealing the signal networks. Frontiers Plant Science 151(5), 1-10. 
Gonzales-zamora A, E Sierra-campos, JG Lunaortega, R Perez-morales, JC Ortiz \& JL Garciahernandez (2013). Characterization of different capsicum varieties by evaluation of their capsaicinoids content by high performance liquid chromatography, determination ofpungency and effect of high temperature. Molecules 18, 13471-13486.

Ibrahim MH \& HZE Jaafar (2013). Absisic acid induced changes in production of primary and secondary metabolites, photosynthetic capacity, antioxidant capability, antioxidant enzymes, and lipooxygenase inhibitory activity of Orthosiphon stamineus Benth. Molecules 18, 7957-7976.

Iriti M, V Picchi, M Possomi, S Gomarasca, N Ludwig, M Gargano \& F Faoro (2009). Chitosan antitranspirant activity is due to absisic acid-dependent stomatal closure. Environmental and Experimental Botany 66, 493-500.

KEMENTAN (2016). Outlook Komoditas Pertanian Sub Sektor Hortikultura : Cabai. Jakarta: Pusat Data dan Sistem Informasi Pertanian, kementerian Pertanian.

Khan AL, JH Shin, HY Jung \& IJ Lee (2014). Regulation of capsaicin synthesis in capsicum annum L. by Penicillium resedanum LK6 during drought condition. Scientia Horticulturae 175, 167-173.

Khan W, B Prithiviraj, Smith \& L Donald (2003). Chitosan and chitin oligomers increase phenylalanine ammonia-lyase and tyrosine ammonia-lyase activities in soybean leaves. Journal of Plant Physiology 160, 859-863.

Kim DS \& BK Hwang (2014). An important role of the pepper phenylalanine ammonia-lyase gen $(P A L 1)$ in salisilic acid-dependent signaling of the defence response to microbial pathogens. Journal of Experimental Botany 65(9), 2295-2306.

Kraikruan W, S Sangchote, \& S Sukprakarn (2008). Effect of Capsaicin on Germination of Colletotrichum capsici Conidia. Kasetsart Journal (Natural Science) 42, 417-422.

Livak KJ \& TD Schmittgen (2001). Analysis of relative gene expression data using real time quantitative pcr and the $2^{-\Delta \Delta \mathrm{C}}$ method. Methods 25, 402-408.

Malerba M \& R Cerana (2016) Chitosan effects on plant system. International Journal of Molecular science 17, 996.
Mejia-teniente L, FD Duran-flores, AM Chapaoliver, I Torres-pacheco, A Cruz-hernandez, M Gonzalez-chavira, M Ocampo-valazquez, V Rosalia \& RG Guevara-gonzalez (2013). Oxydative and molecular responsses in Capsicum annuиm L. after hydrogen peroxyde, salisilic acid and chitosan foliar applications. International Journal of Molecular Science 14, 10178-10196.

Mondal MMA, MA Malek, AB Puteh, MR Ismail, M Ashrafuzzman \& L Naher (2012). Effect of foliar application of chitosan on growth and yield in okra. Australian Journal of Crop Science 6, 918-921.

Mukta JA, M Rahman, AA Sabir, DR Gupta, MZ Surovy, M Rahman \& MT Islam (2017). Chitosan and plant probiotics application enhance growth and yield of strawberry. J Biocatal Agric Biotechnol 11, 9-18.

Phimchan P, S Techawongstein, S Chanthai \& PW Bosland (2012) Impact of drought stress on the accumulation of capsaicinoids in capsicum cultivars with different initial capsaicinoid levels. HortScience 47, 1204-1209.

Pichyangkura R \& S Chadchawan (2015). Biostimulant activity of chitosan in horticulture. Scientia Horticulturae 196, 49-65.

Sung Y, Y Chang \& N Ting (2005). Capsaicin biosynthesis in water-stressed hot pepper fruits. Botanical Bulletin of Academia Sinica 46, 3542.

Veloso J, C Prego, MM Varela, R Carballeira, A Bernal, F Merino \& J Diaz (2013). Properties of capsaicinoids for the control of fungi and oomycetes pathogenic to pepper. Plant Biology $16,177-185$.

Wahyuni S, CA Yusup, DD Eris, SM Putra, AS Mulyani, Siswanto \& Priyono (2019) Peningkatan hasil panen dan penekanan kejadian penyakit pada jagung manis (Zea mays var. Bonanza) dengan pemanfaatan biostimulan berbahan kitosan. Menara Perkebunan 87(2), 131-139.

Wahyuni S, R Selvina, R Fauziyah, HT Prakoso, Priyono \& Siswanto (2020). Optimasi suhu dan waktu deasetilasi kitin berbasis selongsong maggot (Hermetia Illucens) menjadi kitosan. Jurnal Ilmu Pertanian Indonesia 25(3), 375383.

Wasternack C (2013). Action of jasmonates in plants stress responses and development applied aspect. Biotechnology Advances 32(1), 31-39. 